\title{
Current Opinion in Behavioral Sciences
}

Special Issue: New Frontiers for the Integrative Study of Animal Behavior

Neophobia is not only avoidance; improving neophobia tests by combining cognition and ecology

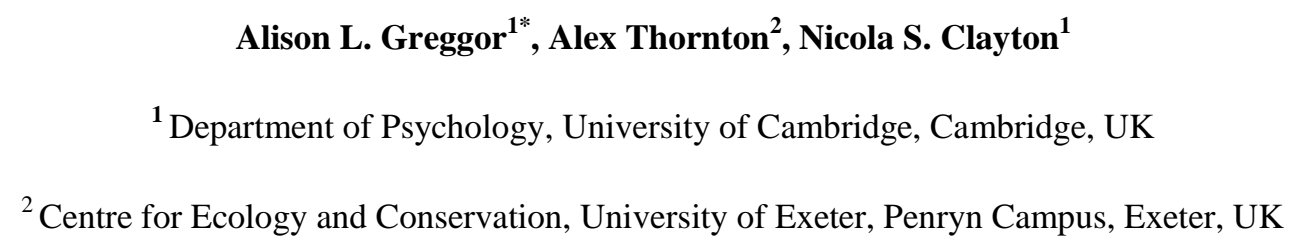




\section{Abstract}

Psychologists and behavioural ecologists use neophobia tests to measure behaviours ranging from anxiety to predatory wariness. Psychologists typically focus on underlying cognitive mechanisms at the expense of ecological validity, while behavioural ecologists generally examine adaptive function but ignore cognition. However, neophobia is an ecologically relevant fear behaviour that arises through a cognitive assessment of novel stimuli. Both fields have accrued conflicting results using various testing protocols, making it unclear what neophobia tests measure and what correlations between neophobia and other traits mean. Developing cognitively and ecologically informed tests allows neophobia to be empirically evaluated where appropriate and controlled for where it interferes with other behavioural measures. We offer guidelines for designing tests and stress the need for interdisciplinary dialogue to better explore neophobia's proximate causes and ecological consequences.

Key words: neophobia, exploration, fear, cognition

\section{Introduction}

Many animals show an aversion to novelty; a behavior known as neophobia. In the wild, avoiding novel predators, foods, objects and locations shapes life history [1] and influences how animals react to new environments [2]. Neophobia was first studied by comparative psychologists in the 1950s [3] to quantify non-human fear, anxiety, curiosity, and memory, and is still commonly used in psychopharmacology and neurobiology for testing drugs and mapping brain circuitry [4]. Only more recently have behavioral ecologists studied neophobic behavior, focusing instead on the adaptive value, evolutionary trade-offs and ecological consequences of variation in neophobia between species, populations and individuals [1]. Boosted by growing evidence that non-human animals exhibit stable individual differences in behavior (i.e. temperament, or personality [5]), neophobia tests have become a common way of comparing variation in personality with other traits. For example, neophobia levels have been reported to be negatively correlated with propensities for behavioral innovation [6] and with decreased physiological stress responses [7]; and to have implications for competitive ability [8], aggression [9] and fitness [10,11].

With so many potential implications, neophobia tests must be rigorous and valid. However, there is no consensus across disciplines on how to measure neophobia or interpret seemingly neophobic behavior. Similar tests—-such as quantifying movement in a novel or 
aversive space - are interpreted variously as measures of context-specific exploration (e.g. spatial neophilia [12]), of general "fearfulness" [13] or anxiety [14]. Conversely, very different methods are used to test neophobia: such as measuring how often animals inspect peep-holes to see novelty [15], measuring latencies to approach novel feeding platforms [16] or consume novel foods [13]. Therefore current testing methods may fall prey to both sides of the jingle-jangle fallacy $[17,18]$ : of lumping together distinct behaviors, or of mislabeling the same trait as two separate attributes. Additionally, there has been little attention to potential differences between species in their perception and subsequent responses to the objects, spaces or foods used for testing, and the choice of novel stimuli is rarely validated against known fearful or known stimuli. These oversights have led to a confusing body of conflicting results (see Table 1). For example, it is unclear how to compare a test that places a green hairbrush in a common myna's (Acridotheres tristis) home cage (e.g. [2]) with one that exposes a fallow deer (Dama dama) to a mirror in an experimental arena (e.g. [19]), particularly when they come to opposite conclusions about whether object neophobia correlates with a latency to eat novel food.

Despite utilizing tests developed by psychologists, behavioral ecologists often ignore the cognition underlying fear behavior, sometimes explicitly (e.g. [5]). Cognition encompasses the mental processes behind perception, learning, decision making and memory (sensu [20]); processes that underlie most behaviour. Crucially, responding to something because of its novelty per se relies on classifying an encountered stimulus as novel.

Therefore, neophobia involves an additional cognitive process to other fear reactions and may not serve as the best measure of overall fearfulness (e.g. [13]), or boldness (e.g. [21,22]). Individuals may differ in how easily they are aroused by fear-inducing stimuli, differ in their generalization and categorization abilities (i.e. whether they classify a stimulus as novel, and therefore fear-provoking), and differ in their experiences from which they define novelty. Neophobia tests that ignore cognition fail to address these distinct processes, and risk misinterpreting both the proximate mechanisms and ultimate function of avoidance behaviour, making apparent correlations between "neophobia" and other behaviors difficult to interpret. For example, albatrosses (Thalassarche melanophrys) differ in how aggressively they react when a pink volleyball approaches their nest [23]; an aggressive response being interpreted as high boldness and related to foraging patterns. However, it is unclear whether the "bolder" birds classify the object as a threat and the "shyer" birds do not, or whether the 
two groups genuinely differ in their neophobia; a crucial distinction for determining their response to novelty in non-threatening situations.

Meanwhile, despite measuring an ecologically important behavior, psychologists often ignore the adaptive context that favors attention towards and fear of novel stimuli. For example, novel stimuli are rarely vetted to ensure they do not incidentally target ecologically relevant cognitive biases towards certain colors, shapes or patterns. Since responses to novelty are commonly used as indicators of memory [4], and stimuli that incidentally target biases may be attended to in higher frequencies than those that do not, psychological tests can be skewed by object design. For example, depending on the species, an object that incorporates the color red may mimic dangerous aposematic prey [24] or an attractive, sexually selected signal (e.g. [25]); thereby producing opposite patterns of avoidance or approach that may be resistant to fatigue, regardless of memory. Additionally, whether fear behaviors are specific to testing situations can be crucial to interpreting results, from the efficacy of drug treatments to the consistency of brain activity across contexts and species. Laboratory animal strains may differ, and even produce contradictory results in identical neophobia tests [26]. Therefore animals' selective history and the stimuli's ecological relevance must be considered to enable accurate comparisons. This paper highlights the importance of considering the cognitive processes and ecological contexts underlying neophobic behavior, and offers suggestions for improving neophobia tests. Ultimately, testing neophobia consistently and accurately will depend on integrating methods from both fields to better understand the proximate causes and ecological consequences of neophobia.

\section{Problems with neophobia tests}

Operationally, neophobia can be divided into the fear of novel objects, spaces, and foods [6]. The fear of novel foods (i.e. dietary wariness) breaks down into two behaviours: fearing the appearance of food (a form of object neophobia) and hesitating to incorporate it regularly into the diet (i.e. dietary conservatism [27]). There is disagreement over whether the types of neophobia correlate and measure the same underlying mechanism. Within the animal personality literature, all types of neophobia are often classified under the same umbrella of exploration-avoidance [5] and are used interchangeably to measure exploration [9,28], and boldness [21,23].

However, whether animals interact with novelty depends on both their fear and their interest (i.e. neophilia) in exploring it $[1,4]$. Neophobia can interfere with measures of 
exploration because the two motivations can in theory occur simultaneously to create ambiguous behaviour [1]. Awareness of this issue is especially important in spatial exploration tests, where response measures gauge movement in a novel environment (NE), with higher movement interpreted as greater exploration [28]. Although these tests have been proven repeatable [29], and to correlate with other traits [30], they require different interpretations if movement stems from fear, curiosity or a combination of the two. For example, object neophobia was found to correlate positively with NE movement in jackdaws (Corvus monedula), suggesting that more fearful birds explored more ([31], Table 1); the opposite of what is expected if movement in NE tasks measure a lack of fear. Perhaps a better explanation is that jackdaws, like other corvids, often display fearfulness by hopping around [32]; so movement may actually indicate spatial neophobia, not curiosity or exploration. Since greater movement in the NE predicted lower reproductive success in this study [27], the cause of the movement is critical to understanding why individual differences influence jackdaw reproductive success.

Even if neophobia involves distinct processes across contexts, separating neophobia tests into strict categories is not always straightforward. For example, coyotes respond differently to novel objects in familiar or unfamiliar environments [33]. Therefore it is unclear whether a novel object in a novel environment tests object neophobia, spatial neophobia, or some interaction of the two. Furthermore, how do we classify neophobia that is extended beyond the artificial objects, spaces, and foods created in the laboratory to more ecologically valid stimuli, such as novel predators (e.g. [34])? Or stimuli that are neither specifically objects nor foods such as aversions to novel odours [35]? The stimulus driven definitions of neophobia seem very simple, yet they risk being arbitrary if not connected to their ecological context and neurological underpinnings. The source of confusion becomes clear when examining the cognitive steps that produce neophobic behaviour.

\section{Combining the cognition and ecology of neophobia}

Animals' subjective experience of fear is unobservable. However, perceiving fearful stimuli triggers measurable endocrine responses, generating observable physiological changes (e.g. increased heartrate and reduced salivation [36]) and avoidance, flight and withdrawal behaviours. The cascade of fear responses is prompted by a cognitive assessment of risk because the sympathetic nervous system will not respond to injury if the brain is experimentally disconnected or unconscious [37]. 
Although current neurobiological evidence has not resolved whether separate types of neophobia involve disparate brain regions, assessing and reacting to novelty involves multiple cognitive processes. Perceiving novelty activates brain regions associated with memory and decision making [38]. Areas within the prefrontal cortex and the hippocampus, along with activity of the neurotransmitter acetylcholine have been implicated experimentally in neophobic and exploratory responses, presumably because they process memory formation, retrieval, and decision making [4,38,39]. Reacting negatively towards novelty activates brain regions associated with fear. For example, lesions to the amygdala and the administration of anxiolytic drugs tend to decrease neophobic behaviors, presumably by dampening fear responses [4]. The physiological effects of activating fear circuitry during neophobic as opposed to general fear behavior are largely unstudied. In linnets (Acanthis cannabina), an increased heartrate has been documented with encountering novelty $(\mathrm{H}$ Gaßmann, PhD Thesis, Aachen University, 1991), and in great tits (Parus major), birds that were slower to explore a NE exhibited a faster and higher peak glucocorticoid stress hormone response after being handled [40]. However, these hormone measures were taken during a fearful event that did not involve novel stimuli. Other work measuring corticosterone levels immediately after encountering novel objects found no such increase [41]. Therefore more work is needed to determine how the cognitive appraisal of novelty leads to the physiological expression of neophobic behavior. Detecting physiological correlates of fear does not imply that behavioural responses stem from a fear of novelty per se; instead, they may result from the categorization of novelty as a known danger (see Figure 1).

Determining the cause of seemingly neophobic behavior has critical ecological implications. Whether animals respond aversively to all novelty or only to novelty that closely resembles a known danger, such as a predator, can greatly impact survival. For instance, in fathead minnows (Pimephales promelas) the more closely related a novel predator is to a known one, the more likely it will elicit anti-predator behaviour [42]. In this case neophobic behaviour may not play a major role in avoiding a novel, invading predator. However, in neophobic species, such as juvenile whitetail damselfish, (Pomacentrus chrysurus) [10], broader avoidance may facilitate naïve individuals' escape from predators without a dangerous learning experience.

From an ecological perspective, each type of neophobia may be expected to evolve in response to different selective pressures [1]. For example, high predation pressure may favour object neophobia if avoiding new stimuli allows animals to escape $[1,43]$. The need to exploit 
different habitats or migrate may promote low spatial neophobia [e.g. 5]. Finally, a high prevalence of dangerous foods may favour dietary wariness to prevent poisoning [44]. Studies testing multiple, closely-related species on various types of neophobia provide evidence for differential selection on neophobia categories. For example different rat species (Rattus norvegicus, Rattus fuscipes, and Rattus villosissimus) have similar levels of spatial neophobia but the brown rat (R. norvegicus), which has an evolutionary history as a human commensal species that regularly encounters rat poison, expresses considerably higher levels of object neophobia [45]. Beyond within-family comparisons (e.g. [46]), however, we know very little about the greater phylogenetic constraints that influence the possible expression of neophobic behavior. Broad, interspecific comparisons are largely absent from the neophobia literature, apart from early studies that did not control for differences in animals' perceptual abilities (e.g. [47]), and therefore phylogenetically controlled analyses are not yet possible.

If behavioural ecologists are interested in animals' responses to novel predators, food, or locations they may benefit from targeting a specific category of neophobia to increase the ecological relevance of the test. Conversely, where the interest is in quantifying an individuals' propensity for overall risk taking, boldness, or general fear reactivity, then tests that avoid the confound of novelty might be more appropriate [5]. While researchers should consider whether neophobia tests or measures of general fear behaviour are more appropriate for their research questions, they can take steps to increase the validity and accuracy of neophobia tests (see Table 2).

\section{How should we test reactions to novelty?}

Novelty is not inherent to any stimulus, but arises through an interaction of perception and memory [4]. In designing an object neophobia test, researchers would benefit from considering whether the properties of an object could fall into an individual's previously held or evolutionarily relevant categories. Species can differ in the manifestation of their fear behaviours (e.g. reacting with flight responses or tonic immobility [48]) and may also possess differing cognitive biases as a result of their evolutionary history, predisposing them to find certain stimuli or situations more frightening than others [17]. For instance, if animals find certain stimulus characteristics, such as aposematic colours [24] or similarity to predator eyes [49], intrinsically aversive, avoidance may not be due to novelty alone. Efforts should be made to design test stimuli that do not inadvertently mimic known fear-related stimuli. 
Additionally, since the complexity of a novel object (e.g. patterning, textures and shape) can influence how much animals interact with it $[1,3,41,50]$, objects with greater complexity may more likely elicit novelty responses. Unfortunately, often little justification is given for choosing seemingly arbitrary objects in behavioural ecology (e.g. a pink plastic key chain [51]; a battery [52]), and psychology (e.g. an aluminium painted cube [45]; see Table 1). Also, despite there being individual consistency in some neophobic responses [53], reactions to different objects can vary considerably [54-56]. Despite the potential variation in responses towards different objects, relying on a single neophobia test is not advisable because at least two measures of a temperament trait are needed to verify its reliability within individuals [5]. Therefore neophobia tests should be repeated with a range of objects-not repeats of the same object (e.g. [23,57]), which are no longer novel on subsequent presentations - to create a more accurate measure of general novelty responses. Alternatively, experiments that aim to test the limits and plasticity of an individual's novelty categories could systematically present objects designed to differ in small yet distinct ways to help define which aspects of a stimulus contribute to its novelty.

Reactions to novelty may combine fear, interest and indifference. Several methodological details can help tease apart fear from exploration interest (i.e. neophilia). For example, tests that measure animals' hesitancies to venture outside a familiar space may differ critically from those in which animals are forced into novel environments, where activity may be better explained by motivation to escape [17,58]. Both fearfulness and curiosity can be assessed by combining these two types of tests: measuring animals' latencies to enter (neophobia), and their subsequent exploration of a novel space (e.g. [12]). Similarly, neophobia can be measured through tests that compare approach latencies towards a reward such as food with latencies towards food next to a novel object (e.g. [59]). Conversely, tests where the only motivation for approaching an object is the object itself measure exploration (e.g. [60]). These two tests do not always correlate [46]. Additionally, behaviour in a neophobia test might be confounded by reactions to stressors other than the novelty presented. For example, if spatial exploration negatively correlates with object neophobia (e.g. [57]) — the opposite relationship to that reported with jackdaws [31] - it could mean that individuals classified as most explorative may be faster to recover and resume normal behaviour following a general stressor (e.g. [40]), such as being handled. In the absence of a control measurement of normal behaviour, (e.g. activity around a familiar object), it is harder to determine whether avoidance behaviour is neophobia [51], or movement is explorative. 
Ultimately, the ability of neophobia tests to be predictive in future situations and contexts depends on understanding what drives seemingly neophobic behavior: differences in fear reactivity, information processing, or past experience. Pairing neophobia tests with measures of behavior towards known fearful stimuli, or with other tests of general fearfulness, such as startle tests that measure how long animals take to resume normal behavior after being surprised [52], may help determine whether differences stem from variation in fear reactivity. Accordingly, sometimes other fear-related behaviors correlate with neophobia [61], and other times they do not $[62,63]$, potentially indicating situations where neophobic responses are influenced by information processing, not fear. Pairing neophobia tests with cognitive measures, such as habituation, categorization, or memory tests is rarely done, but could help determine whether differences stem from classifying novelty. Just as general cognitive ability may best be determined though batteries of tests targeting specific cognitive processes [64], neophobia tests will be more accurate with thoughtfully constructed stimuli and multiple measures to determine an individual's propensity for fear across contexts. In future, such test batteries may help to determine why neophobic behaviors correlate with other traits, and determine the extent of within- and between- individual variation in different measures of neophobia, ultimately helping to reveal both the proximate mechanisms and evolutionary consequences of neophobia.

\section{Conclusions}

Controlled laboratory studies and ecologically relevant field experiments have equal importance in moving the study of neophobia towards more informed tests. We need psychologists to ascertain the mechanisms, and behavioral ecologists to explain why neophobic behavior exists. Greater communication between the fields, and between overlapping disciplines such those connecting personality and potential "cognitive styles"(e.g. [65]) will facilitate the development of more valid stimuli and of tests targeting specific types of neophobia. With accurate neophobia tests, we can confirm whether neophobia should be separated into distinct categories and whether all categories need to be sampled to measure overall fearfulness. Ultimately, making these distinctions will help determine why neophobia exists, and how its expression impacts individuals and species.

\section{Acknowledgements}

We would like to thank Alecia Carter for helpful discussion and comments on the manuscript and to thank two anonymous reviewers and the editor, Dr. Hofmann, for their thoughtful and 
insightful feedback. A.L.G. received generous support from the Gates-Cambridge Trust; A.T. is funded by a BBSRC David Phillips Fellowship (BB/H021817/1)

\section{References}

*1. Greenberg R, Mettke-Hofmann C: Ecological aspects of neophobia and neophilia in birds. In Current Ornithology. Edited by Nolan Jr V, Thompson CF. 2001:119-178.

2. Sol D, Griffin AS, Bartomeus I, Boyce H: Exploring or avoiding novel food resources? The novelty conflict in an invasive bird. [Internet]. PLoS One 2011, 6:e19535.

3. Berlyne DE: Novelty and curiosity as determinants of exploratory behaviour. $\mathrm{Br}$. J. Psychol. 1950, 41:68-80.

4. Hughes RN: Neotic preferences in laboratory rodents: issues, assessment and substrates. [Internet]. Neurosci. Biobehav. Rev. 2007, 31:441-64.

5. Réale D, Reader SM, Sol D, McDougall PT, Dingemanse NJ: Integrating animal temperament within ecology and evolution. [Internet]. Biol. Rev. Camb. Philos. Soc. 2007, 82:291-318.

6. Greenberg R: The role of neophobia and neophilia in the development of innovative behaviour of birds. In Animal Innovation. Edited by Laland KN, Reader SM. 2003:175-196.

7. Carere C, van Oers K: Shy and bold great tits (Parus major): body temperature and breath rate in response to handling stress. [Internet]. Physiol. Behav. 2004, 82:905-12.

8. Cole EF, Quinn JL: Personality and problem-solving performance explain competitive ability in the wild. [Internet]. Proc. Biol. Sci. 2012, 279:1168-75.

9. Verbeek MEM, Boon A, Drent PJ: Exploration, Aggressive Behaviour and Dominance in Pair-Wise Confrontations of Juvenile Male Great Tits. Behaviour 1996, 133:945-963.

**10. Ferrari MCO, Mccormick MI, Meekan MG, Chivers DP: Background level of risk and the survival of predator-naive prey : can neophobia compensate for predator naivety in juvenile coral reef fishes? [Internet]. Proc. R. Soc. B Biol. Sci. 2015, 282. The authors released fish with manipulated levels of neophobia into the wild and measured survival. This is one of the first studies providing evidence of the fitness benefits of neophobia by linking levels of increased juvenile neophobia with higher survival.

11. Smith BR, Blumstein DT: Fitness consequences of personality: a meta-analysis [Internet]. Behav. Ecol. 2008, 19:448-455. 
*12. Mettke-Hofmann C, Lorentzen S, Schlicht E, Schneider J, Werner F: Spatial Neophilia and Spatial Neophobia in Resident and Migratory Warblers ( Sylvia ) [Internet]. Ethology 2009, 115:482-492.

13. Villalba JJ, Manteca X, Provenza FD: Relationship between reluctance to eat novel foods and open-field behavior in sheep. [Internet]. Physiol. Behav. 2009, 96:27681.

14. Bourin M, Hascoët M: The mouse light/dark box test [Internet]. Eur. J. Pharmacol. 2003, 463:55-65.

15. File SE, Wardill AG: Validity of Head-Dipping as a Measure of Exploration in a Modified Hole-Board. Psychopharmacologia 1975, 59:53-59.

16. Rockwell C, Gabriel PO, Black JM: Bolder, older, and selective: factors of individual-specific foraging behaviors in Steller's jays [Internet]. Behav. Ecol. 2012, 23:676-683.

**17. Carter AJ, Feeney WE, Marshall HH, Cowlishaw G, Heinsohn R: Animal personality: what are behavioural ecologists measuring? [Internet]. Biol. Rev. Camb. Philos. Soc. 2013, 88:465-75.

A critical review of terminology and methodology used in animal personality studies. One of the first studies to clearly explain the issues surrounding personality tests and to offer reccomendations on how best to measure boldness.

18. Gosling SD: From mice to men: What can we learn about personality from animal research? [Internet]. Psychol. Bull. 2001, 127:45-86.

19. Bergvall U a., Schäpers A, Kjellander P, Weiss A: Personality and foraging decisions in fallow deer, Dama dama [Internet]. Anim. Behav. 2011, 81:101-112.

20. Shettleworth S: Cognition, Evolution, and Behaviour. Oxford University Press; 2010.

21. Atwell JW, Cardoso GC, Whittaker DJ, Campbell-nelson S, Robertson KW, Ketterson ED: Boldness behavior and stress physiology in a novel urban environment suggest rapid correlated evolutionary adaptation. Behav. Ecol. 2012, doi:10.1093/beheco/ars059.

22. Kurvers RHJM, van Oers K, Nolet B a, Jonker RM, van Wieren SE, Prins HHT, Ydenberg RC: Personality predicts the use of social information. [Internet]. Ecol. Lett. 2010, 13:829-37.

23. Patrick SC, Weimerskirch $\mathrm{H}$ : Personality, foraging and fitness consequences in a long lived seabird. [Internet]. PLoS One 2014, 9:e87269.

24. Roper ATJ, Cook SE: Responses of Chicks to Brightly Coloured Insect Prey. Behaviour 1989, 110:276-293.

25. Karubian J: Costs and Benefits of Variable Breeding Plumage in the Red-Backed Fairy-Wren. Evolution 2002, 56:1673-1682. 
26. Bert B, Fink H, Sohr R, Rex A: Different effects of diazepam in Fischer rats and two stocks of Wistar rats in tests of anxiety. Pharmacol. Biochem. Behavor 2001, 70:411-420.

27. Marples NM, Kelly DJ: Neophobia and dietary conservatism : two distinct processes ? Evol. Ecol. 2001, 13:641-653.

28. Verbeek M: Consistent individual differences in early exploratory behaviour of male great tits. Anim. Behav. 1994, 48:1113-1121.

29. Quinn JL, Patrick SC, Bouwhuis S, Wilkin TA, Sheldon BC: Heterogeneous selection on a heritable temperament trait in a variable environment. J. Anim. Ecol. 2009, 78:1203-1215.

30. Quinn JL, Cole EF, Bates J, Payne RW, Cresswell W: Personality predicts individual responsiveness to the risks of starvation and predation. [Internet]. Proc. R. Soc. B Biol. Sci. 2012, 279:1919-26.

31. Schuett W, Laaksonen J, Laaksonen T: Prospecting at conspecific nests and exploration in a novel environment are associated with reproductive success in the jackdaw [Internet]. Behav. Ecol. Sociobiol. 2012, 66:1341-1350.

32. Heinrich B: Why Do Ravens Fear Their Food ? Condor 1988, 90:950-952.

33. Harris CE, Knowlton FF: Differential responses of coyotes to novel stimuli in familiar and unfamiliar settings [Internet]. Can. J. Zool. 2001, 79:2005-2013.

*34. Brown GE, Ferrari MCO, Elvidge CK, Ramnarine I, Chivers DP: Phenotypically plastic neophobia: a response to variable predation risk. [Internet]. Proc. Biol. Sci. 2013, 280:20122712.

The authors experimentally altered neophobia levels by manipulating the amount of alarm cues animals experienced. This is the first demonstration that neophobia expression responds to environmental influences.

35. Jetz W, Rowe C, Guilford T: Non-warning odors trigger innate color aversions as long as they are novel. Behav. Ecol. 2001, 12:134-139.

36. Thomson R: The Concept of Fear. In Fear in Animals and Man. Edited by Sluckin W. Van Nostrand Reinhold Company; 1979:1-23.

37. Mayes A: The Physiology of Fear and Anxiety. In Fear in Animals and Man. Edited by Sluckin W. Van Nostrand Reinhold Company; 1979:24-55.

38. Ranganath $\mathrm{C}$, Rainer $\mathrm{G}$ : Neural mechanisms for detecting and remembering novel events. [Internet]. Nat. Rev. Neurosci. 2003, 4:193-202.

39. Løvstad M, Funderud I, Lindgren M, Endestad T, Due-tønnessen P, Meling T, Voytek B, Knight RT, Solbakk A: Contribution of Subregions of Human Frontal Cortex to Novelty Processing. J. Cogn. Neurosci. 2011, 24:378-395. 
*40. Baugh AT, van Oers K, Naguib M, Hau M: Initial reactivity and magnitude of the acute stress response associated with personality in wild great tits (Parus major). [Internet]. Gen. Comp. Endocrinol. 2013, 189:96-104.

Slow exploreres in a novel environment task had faster and higher stress hormone responses to a stressful event. One of the few studies linking exploration to phyioslogical measures of fear.

41. Mettke-Hofmann C, Rowe KC, Hayden TJ, Canoine V: Effects of experience and object complexity on exploration in garden warblers (Sylvia borin) [Internet]. $J$. Zool. 2006, 268:405-413.

*42. Ferrari MCO, Gonzalo A, Messier F, Chivers DP: Generalization of learned predator recognition: an experimental test and framework for future studies. [Internet]. Proc. Biol. Sci. 2007, 274:1853-9.

43. Brown GE, Chivers DP, Elvidge CK, Jackson CD, Ferrari MCO: Background level of risk determines the intensity of predator neophobia in juvenile convict cichlids [Internet]. Behav. Ecol. Sociobiol. 2013, doi:10.1007/s00265-013-1629-z.

44. Thornton A: Social learning about novel foods in young meerkats [Internet]. Anim. Behav. 2008, 76:1411-1421.

45. Cowan PE: Neophobia and Neophilia : New-Object and New-Place Reactions of Three Rattus Species. J. Comp. Physiol. Psychol. 1977, 91:63-71.

46. Mettke-hofmann C, Winkler H, Leisler B: The Significance of Ecological Factors for Exploration and Neophobia in Parrots. Ethology 2002, 272.

47. Glickman SE, Sroges RW: Curiosity in Zoo Animals Stable. Behaviour 1966, 26:151-188.

48. Archer J: Behavioural aspects of fear. In Fear in Animals and Man. Edited by Sluckin W. Van Nostrand Reinhold Company; 1979:56-85.

49. Vallin A, Jakobsson S, Lind J, Wiklund C: Prey survival by predator intimidation: an experimental study of peacock butterfly defence against blue tits. [Internet]. Proc. Biol. Sci. 2005, 272:1203-7.

50. Jones RB, Larkins C, Hughes B: Approach / avoidance responses of domestic chicks to familiar and unfamiliar video images of biologically neutral stimuli. Appl. Anim. Behav. Sci. 1996, 48.

*51. Fox R a, Ladage LD, Roth TC, Pravosudov V V: Behavioral profile predicts dominance status in mountain chickadees, Poecile gambeli [Internet]. Anim. Behav. 2009, 77:1441-1448.

52. Martins TLF, Roberts ML, Giblin I, Huxham R, Evans MR: Speed of exploration and risk-taking behavior are linked to corticosterone titres in zebra finches. [Internet]. Horm. Behav. 2007, 52:445-53. 
53. Dingemanse $\mathrm{N}$ : Repeatability and heritability of exploratory behaviour in great tits from the wild [Internet]. Anim. Behav. 2002, 64:929-938.

54. Heinrich B: Neophilia and exploration in juvenile common ravens,. Anim. Behav. 1995, 50:695-704.

55. Greenberg R: The Role of Neophobia in Determining the Degree of Foraging Specialization in Some Migrant Warblers. Am. Nat. 1983, 122:444-453.

56. Heyser CJ, Chemero A: Novel object exploration in mice: not all objects are created equal. [Internet]. Behav. Processes 2012, 89:232-8.

*57. Cole EF, Quinn JL: Shy birds play it safe : personality in captivity predicts risk responsiveness during reproduction in the wild. Biol. Lett. 2014, 10.

58. Hughes RN: Intrinsic exploration in animals : motives and measurement. Behav. Processes 1997, 41:213-226.

59. Greenberg R: Differences in Neophobia between Naive Song and Swamp Sparrows. Ethology 1992, 24:17-24.

60. Mettke-Hofmann C: Object Exploration of Garden and Sardinian Warblers Peaks in Spring [Internet]. Ethology 2007, 113:174-182.

61. Turro-Vincent L, Launey F, Mills AD, Picard M, Faure JM: Experimental and genetic influence on learnt food aversions in Japanese quail selected for high and low levels of fearfulness. Behav. Processes 1995, 34:23-41.

62. Seferta A, Guay P, Marzinotto E, Lefebvre L: Learning differences between feral pigeons and zenaida doves: the role of neophobia and human proximity. Ecology 2001, 107:281-293.

63. Carter AJ, Marshall HH, Heinsohn R, Cowlishaw G: How not to measure boldness: novel object and antipredator responses are not the same in wild baboons [Internet]. Anim. Behav. 2012, 84:603-609.

*64. Thornton a., Isden J, Madden JR: Toward wild psychometrics: linking individual cognitive differences to fitness [Internet]. Behav. Ecol. 2014, 00:1-3.

The authors offer a timely critique of behavioral studies that quantify non-human cognition, recommending that specific cognitive processes are targetted with each test. Their persepctive allows for the connection of cognitive differences to fitness consequences.

65. Sih A, Del Giudice M: Linking behavioural syndromes and cognition: a behavioural ecology perspective. [Internet]. Philos. Trans. R. Soc. Lond. B. Biol. Sci. 2012, 367:2762-72.

66. Schuett W, Godin J-GJ, Dall SRX: Do Female Zebra Finches, Taeniopygia guttata, Choose Their Mates Based on Their "Personality"? [Internet]. Ethology 2011, 117:908-917. 
67. Boogert NJ, Reader SM, Laland KN: The relation between social rank, neophobia and individual learning in starlings [Internet]. Anim. Behav. 2006, 72:1229-1239.

68. Marples NM, Brakefield PM: Genetic variation for the rate of recruitment of novel insect prey into the diet of a bird. Biol. J. Linn. Soc. 1995, [no volume].

69. Coleman K, Wilson DS: Shyness and boldness in pumpkinseed sunfish: individual differences are context-specific. Anim. Behav. 1998, 56:927-936.

70. Ruuskanen S, Laaksonen T: Yolk hormones have sex-specific long-term effects on behavior in the pied flycatcher (Ficedula hypoleuca). [Internet]. Horm. Behav. 2010, 57:119-27. 
Table 1. Sample of conflicting neophobia tests. $\mathrm{W}=\mathrm{Wild}, \mathrm{C}=\mathrm{Captive}, \mathrm{WC}=\mathrm{Wild}$-caught. $\mathrm{Ob}=$ latency to approach a novel object; $\mathrm{Sp}=$ amount of movement in a novel space; $\mathrm{DC}=$ amount of time before incorporating a novel food into the diet (dietary conservatism); Cort= magnitude of coricosterone response; Startle= latency to resume normal behavior after a sudden, frightening event; TI= time spent immobile after being restrained; (+), (-), (/) refer to positive, negative, and no relationship between the two variables; ?= unknown. $\mathrm{NE}=$ Novel environment. *Experimental outdoor ponds open to predation pressure.

\begin{tabular}{|c|c|c|c|c|c|c|}
\hline Species & $\begin{array}{l}\text { Wild or } \\
\text { captive }\end{array}$ & Correlations & Novel stimuli (\# trials) & $\begin{array}{l}\text { Forced } \\
\text { entry to } \\
\text { NE }\end{array}$ & $\begin{array}{l}\text { Reward near } \\
\text { novelty }\end{array}$ & $\begin{array}{l}\text { Compared to } \\
\text { familiar } \\
\text { stimuli }\end{array}$ \\
\hline $\begin{array}{l}\text { Jackdaw } \\
\text { (Corvus monedula) } \\
\text { [31] }\end{array}$ & $\mathrm{W}$ & $\mathrm{Ob}(+) \mathrm{Sp}$ & $\begin{array}{l}\text { stuffed toy (1) } \\
\text { NE (1) }\end{array}$ & $Y$ & $Y$ & $\mathrm{~N}$ \\
\hline $\begin{array}{l}\text { zebra finch } \\
\text { (Taeniopygia } \\
\text { guttata) [66] }\end{array}$ & $\mathrm{C}$ & $\begin{array}{l}\text { Males: Ob (+) Sp } \\
\text { Females: Ob (/) Sp }\end{array}$ & $\begin{array}{l}\text { green woolly ball }(1) \\
\text { NE (2) }\end{array}$ & $\mathrm{N}$ & $\mathrm{N}$ & $\mathrm{N}$ \\
\hline $\begin{array}{l}\text { mountain } \\
\text { chickadee } \\
\text { (Poecile gambeli) } \\
\text { [51] }\end{array}$ & WC & $\mathrm{Ob}(/) \mathrm{Sp}$ & $\begin{array}{l}\text { plastic pink panther key chain (1) } \\
\mathrm{NE}(1)\end{array}$ & $\mathrm{N}$ & $\mathrm{N}$ & $\begin{array}{l}\text { Y (Ob) } \\
\text { N (Sp) }\end{array}$ \\
\hline $\begin{array}{l}\text { Starlings (Sturnus } \\
\text { vulgaris) [67] }\end{array}$ & WC & $\mathrm{Ob}(/) \mathrm{SP}$ & $\begin{array}{l}\text { coloured clothes pins, styrofoam } \\
\text { mounted on cardboard, yellow } \\
\text { reflective material, white opaque } \\
\text { tube cap ,white spool of purple } \\
\text { wire, green pen cap (variable) } \\
\text { NE (variable) }\end{array}$ & $Y$ & $Y$ & $\begin{array}{l}Y(\mathrm{Ob}) \\
\mathrm{N}(\mathrm{Sp})\end{array}$ \\
\hline $\begin{array}{l}\text { zebra finch } \\
\text { (Taeniopygia } \\
\text { guttata) [52] }\end{array}$ & $\mathrm{C}$ & $\begin{array}{l}\mathrm{Ob}(/) \mathrm{SP} \\
\text { Cort }(+) \text { Startle }\end{array}$ & $\begin{array}{l}\text { AA battery, green purse (2) } \\
\text { NE (2) }\end{array}$ & $Y$ & $\begin{array}{l}N(\mathrm{Ob}) \\
\mathrm{Y}(\mathrm{SP}) \\
\mathrm{Y}(\text { Startle })\end{array}$ & $\begin{array}{l}N(\mathrm{Ob}) \\
\mathrm{N}(\mathrm{SP}) \\
\mathrm{Y}(\text { Startle })\end{array}$ \\
\hline
\end{tabular}




\begin{tabular}{|c|c|c|c|c|c|c|}
\hline $\begin{array}{l}\text { Great tit (Parus } \\
\text { major) [28] }\end{array}$ & $\mathrm{C}$ & $\mathrm{Ob}(-) \mathrm{Sp}$ & $\begin{array}{l}\text { penlight battery, pink panther toy } \\
\text { (variable) } \\
\text { NE (1) }\end{array}$ & $?$ & $\begin{array}{l}\mathrm{N}(\mathrm{Ob}) \\
\mathrm{Y}(\mathrm{Sp})\end{array}$ & $\begin{array}{l}\text { Y (Ob) } \\
\text { N (Sp) }\end{array}$ \\
\hline $\begin{array}{l}\text { Great tit (Parus } \\
\text { major) [57] }\end{array}$ & WC, W & $\mathrm{Ob}(-) \mathrm{Sp}$ & $\begin{array}{l}\text { Rigid black and white flag }(1,2) \\
\text { NE (1) }\end{array}$ & $?$ & $\begin{array}{l}Y(\mathrm{Ob}) \\
\mathrm{N}(\mathrm{Sp})\end{array}$ & $\begin{array}{l}Y(\mathrm{Ob}) \\
\mathrm{N}(\mathrm{Sp})\end{array}$ \\
\hline $\begin{array}{l}\text { Japanese Quail } \\
\text { (Coturnix } \\
\text { juponica)[61] }\end{array}$ & C & $\begin{array}{l}\text { Food neo }(/) \mathrm{TI} \\
\mathrm{DC}(+) \mathrm{TI}\end{array}$ & $\begin{array}{l}\text { colored jackbean and field beans } \\
\text { (variable) }\end{array}$ & NA & $\mathrm{N}$ & $\mathrm{N}$ \\
\hline $\begin{array}{l}\text { Japanese Quail } \\
\text { (Coturnix } \\
\text { juponica)[68] }\end{array}$ & $\mathrm{C}$ & $\mathrm{Sp}(/) \mathrm{DC}$ & $\begin{array}{l}\text { Seven spot ladybirds (Adalia } \\
\text { bipunctata) (5) } \\
\text { NE }(1,2)\end{array}$ & $\mathrm{Y}$ & $\mathrm{Y}$ & $\begin{array}{l}Y(D C) \\
Y(S p)\end{array}$ \\
\hline $\begin{array}{l}\text { Pumpkinseed fish } \\
\text { (Lepomis } \\
\text { gibbosus) [69] }\end{array}$ & $W^{*}$ & Ob (/) Food neo & $\begin{array}{l}\text { Metre stick (variable) } \\
\text { Aquatic vegetation (variable) }\end{array}$ & NA & $\mathrm{N}$ & $\mathrm{N}$ \\
\hline $\begin{array}{l}\text { pied-flycatchers } \\
\text { (Ficedula } \\
\text { hypoleuca) [70] }\end{array}$ & WC & $\begin{array}{l}\text { Ob }(+) \text { predator } \\
\text { disturbance } \\
\mathrm{Ob}(/) \mathrm{Sp}\end{array}$ & $\begin{array}{l}\text { pink and yellow plastic duck (2) } \\
\text { Sparrow hawk mount }(1) \\
\text { NE (2) }\end{array}$ & $\mathrm{Y}$ & $\begin{array}{l}\mathrm{N}(\mathrm{Ob}) \\
\mathrm{N}(\mathrm{Sp}) \\
\mathrm{Y} \text { (predator } \\
\text { disturbance) }\end{array}$ & $\mathrm{N}$ \\
\hline $\begin{array}{l}\text { Chacma baboons } \\
\text { (Papio ursinus) } \\
\text { [63] }\end{array}$ & W & $\begin{array}{l}\text { Ob (/) Predator } \\
\text { wariness }\end{array}$ & Food pieces & NA & $\mathrm{N}$ & $\mathrm{N}$ \\
\hline
\end{tabular}


Figure 1. Blending the cognitive processes with ecological pressures in the expression of avoidance behaviour. Routes through which a stimulus can elicit avoidance behaviour; only the route with boxes is neophobia. Previous experience with similar types of novelty can influence the reaction towards subsequent encounters of novel things.

(see separate file) 
Table 2. What to consider when designing a neophobia test.

\begin{tabular}{|c|c|c|}
\hline Test & Things to consider & Why \\
\hline \multirow[t]{4}{*}{ Object Neophobia } & Careful selection of objects & $\begin{array}{l}\text { Ecologically relevant stimuli } \\
\text { can trigger innate fear } \\
\text { responses. Novelty increases } \\
\text { with stimulus complexity } \\
\text { (patterns, colors, textures). }\end{array}$ \\
\hline & $\begin{array}{l}\text { Conduct at least } 2 \text { replicates } \\
\text { each with a new object }\end{array}$ & $\begin{array}{l}\text { Many animals show } \\
\text { repeatability, but can respond } \\
\text { to objects differently. } \\
\text { Responses to novelty will } \\
\text { decrease with repeated } \\
\text { presentations }\end{array}$ \\
\hline & $\begin{array}{l}\text { Does test measure } \\
\text { exploration or fear? }\end{array}$ & $\begin{array}{l}\text { Hesitancy to approach novelty } \\
\text { alongside a reward shows fear } \\
\text { responses. } \\
\text { Exploration is best measured } \\
\text { as an attraction to novelty } \\
\text { without other rewarding } \\
\text { stimuli present. }\end{array}$ \\
\hline & $\begin{array}{l}\text { Is neophobic behavior } \\
\text { compared to normal } \\
\text { behavior? }\end{array}$ & $\begin{array}{l}\text { Without a control it is difficult } \\
\text { to determine whether behavior } \\
\text { is particular to the novel } \\
\text { situation }\end{array}$ \\
\hline \multirow[t]{3}{*}{ Spatial exploration } & $\begin{array}{l}\text { Is the animal forced to enter } \\
\text { a novel space? }\end{array}$ & $\begin{array}{l}\text { Forced entry can lead to fear, } \\
\text { not exploratory behavior }\end{array}$ \\
\hline & $\begin{array}{l}\text { Was the animal handled } \\
\text { beforehand? }\end{array}$ & $\begin{array}{l}\text { Minimize other fearful stimuli } \\
\text { where possible }\end{array}$ \\
\hline & $\begin{array}{l}\text { Is it compared to a measure } \\
\text { of activity in a familiar } \\
\text { area? }\end{array}$ & $\begin{array}{l}\text { Movement in novel space } \\
\text { could otherwise reflect } \\
\text { activity }\end{array}$ \\
\hline Food Neophobia & $\begin{array}{l}\text { Distinguish between } \\
\text { neophobia of the food and } \\
\text { dietary conservatism }\end{array}$ & $\begin{array}{l}\text { Dietary wariness is made up } \\
\text { of two separate processes }\end{array}$ \\
\hline \multirow[t]{3}{*}{ General Neophobia } & $\begin{array}{l}\text { Consider species-specific } \\
\text { fear responses }\end{array}$ & $\begin{array}{l}\text { Species differ in their } \\
\text { cognitive biases }\end{array}$ \\
\hline & $\begin{array}{l}\text { If research questions are } \\
\text { specific to one type of } \\
\text { neophobia, specifically } \\
\text { target that type }\end{array}$ & $\begin{array}{l}\text { Testing one type alone may be } \\
\text { more ecologically relevant }\end{array}$ \\
\hline & $\begin{array}{l}\text { Pair neophobia tests with } \\
\text { other types of tests to tease } \\
\text { apart mechanisms }\end{array}$ & $\begin{array}{l}\text { Pair with a general fearfulness } \\
\text { and an information-processing } \\
\text { test }\end{array}$ \\
\hline
\end{tabular}


